\title{
Museographic Transposition: The Development of a Museum Exhibit on Animal Adaptations to Darkness
}

\section{Marianne Foss Mortensen}

\section{(2) OpenEdition Journals}

Electronic version

URL: http://journals.openedition.org/educationdidactique/763

DOI: $10.4000 /$ educationdidactique.763

ISBN: 978-2-7535-1623-6

ISSN: $2111-4838$

Publisher

Presses universitaires de Rennes

\section{Printed version}

Date of publication: 1 May 2010

Number of pages: $115-138$

ISBN: 978-2-7535-1118-7

ISSN: 1956-3485

\section{Electronic reference}

Marianne Foss Mortensen, « Museographic Transposition: The Development of a Museum Exhibit on Animal Adaptations to Darkness », Éducation et didactique [Online], 4-1 | 2010, Online since 01 April 2012, connection on 08 December 2020. URL : http://journals.openedition.org/educationdidactique/ 763 ; DOI : https://doi.org/10.4000/educationdidactique.763 


\title{
MUSEOGRAPHIC TRANSPOSITION: THE DEVELOPMENT OF A MUSEUM EXHIBIT ON ANIMAL ADAPTATIONS TO DARKNESS
}

\author{
Marianne Foss Mortensen (University of Copenhagen)
}

\begin{abstract}
Science museums define the objectives of their exhibitions in terms of visitor learning outcomes, yet exhibition engineering staff lack theoretical and empirical research findings on which to base the creation of these educational environments. Here, a first step towards providing such research is reported. Museographic transposition was used as an analytical framework to investigate the development of an existing museum exhibit on animal adaptations to darkness. The analysis yielded a descriptive model of exhibition engineering as a three-stage process in which simultaneous processes of epistemological development and museum-pedagogical development result in the curatorial brief which forms the basis of the subsequent museographic development of the physical exhibit. Examples are discussed which illustrate the use of the model in identifying exhibition inconsistencies, but also in generating new ideas for exhibition engineering. The potential for further developing the model is discussed.
\end{abstract}

Key words: museum, exhibit, museographic transposition, animal adaptations, informal science education, exhibit design.

Acknowledgements: I acknowledge the constructive comments of Carl Winsløw, Robert Evans, and two anonymous reviewers on an earlier version of this manuscript. The gracious participation of the four exhibition engineers from Experimentarium and RBINS is also gratefully acknowledged.

Marianne Foss Mortensen

\section{Introduction}

The objectives of science museums are often stated in terms of visitor educational outcomes, and the primary medium of a museum's education activities is the exhibition (Lord, 2002, p. 1). In spite of this educational emphasis, there is little research available to exhibition creators on how to achieve such goals, and exhibition engineering (the process of originating, developing, and implementing an exhibition) thus remains largely based on the tacit professional knowledge of museum staff rather than theoretical underpinnings or empirical evidence.

The sheer quantity of museum research that has been carried out in the last decades seems to contradict this statement. However, the applicability of this work to exhibition engineering is restricted by two characteristics: first, the focus of this work is typically the visitor rather than the exhibition. Second, the research seeks to describe strategies for supporting museum learning that are broadly generalisable and thus often somewhat removed of the exhibition's content.

It is not surprising that museum research devotes considerable attention to the visitor; after all, they are the raison d'être of any museum exhibition. However, the physical exhibition, not the visitor, is the only thing over which the exhibition engineer has direct control (Ansbacher, 1999), and thus the application of research findings pertaining to the visitor can only indirectly influence exhibition engineering. Furthermore, the underlying assumption of finding content-independent educational strategies is that incorporating these strategies into exhibition design will precipitate visitor learning regardless of the subject matter of the exhibition. Yet, research shows that thinking and problem solving are always modulated by the content of the task at hand (Schauble et al., 2002), and exhibition engineering can thus not ignore the specific content that is to be exhibited. In order to conduct research that is applicable to 
the engineering of educational exhibitions, a different approach is needed: one may say that besides museum pedagogy, museum didactics is needed.

\begin{abstract}
Aims
This paper aims to present and exemplify a framework for the content-based analysis of exhibition engineering using as a case an existing exhibition unit at a Danish science centre. The analysis will yield a descriptive model of exhibition development which both encompasses and manages the complexity of the process. Specifically, the model will be used to answer the following research question: What is the nature of the constraints and opportunities which govern the putting-into-exhibition of a specific object of knowledge? More generally, the potential of the model for improving and innovating exhibition engineering will be assessed and discussed. Finally and perhaps most important, the descriptive model will form the first component of a larger research project intended to provide a prescriptive model for exhibition engineering. The findings presented here will thus inform the next step of this process, the investigation of visitor interactions with and understanding of the exhibition unit in question.
\end{abstract}

\section{Theoretical Framework}

\section{Knowledge Transformation in the Exhibition Engineering Process}

The theory of didactic transposition (Chevallard, 1991) originated in the didactics of mathematics but has since then been extended to other disciplines. It will be considered and developed here as a framework for analysing the process of exhibition engineering. The most important assumption of this theory is that the minimal unity of analysis of any didactic situation cannot be limited to how the learner learns, but must consider the process which makes an object of teaching from an object of knowledge to be taught (Chevallard, 1991); a process which involves a deconstruction and a rebuilding of the different components of knowledge with the aim of making it teachable (Bosch \& Gascón,
2006). By emphasising the transformation of an object of knowledge in its passage from the scientific context to the teaching context, the framework of didactic transposition at the same time suggests an inquiry into this transformation and provides the primary means to perform the inquiry. It offers a method to exercise or gauge epistemological vigilance (Chevallard, 1991), i.e. the consistency of the relationship between the created didactic object of knowledge and its scientific origin.

Consider the following example of didactic transposition: a cell biologist may perceive of an animal cell as any member of a highly diverse group, e.g. red blood cells, liver cells, or epidermal cells. However, Clément (2007) found that primary school textbook illustrations often show a decidedly didactic object: a prototypical version of an animal cell which combines the attributes of many different types of cells without corresponding exactly to any single type. The deconstruction and reconstruction of knowledge involved in the creation of this didactic object serves the purpose of establishing the general domain of the animal cell; a general domain into which children can then progressively integrate singular types of animal cells possessing both the general attributes as well as more specific ones (Clément, 2007). However, upon further analysis, Clément found that animal cells in many textbooks are illustrated as singular, isolated cells, which does not reflect the multicellular nature of animal tissue. Clément suggests that this shortcoming could be an obstacle to learning; in the present case, it may be thought of as an example of a lack of consistency between the created didactic object and the scientific object of knowledge which precipitated it.

The adaptive transformation of knowledge that takes place in a museum exhibition engineering context, museographic transposition, was first studied by Simonneaux and Jacobi (1997) who conceived of the process as the transposition of an object of knowledge contained in scientific literature and other sources to an object of knowledge contained in the exhibition (Figure $1 \mathrm{~A}$ ). This conception was expanded by Gouvêa de Sousa et al. (2002) to encompass three moments of transformation of knowledge: preparation, execution, and the visit to the exhibition. Preparation corresponds to the transition between scientific source knowledge and the strategy to put it on exhibition. The second moment, execution, 
marks the installation of that knowledge into space - the physical implementation of the exhibition. The third moment, the visit, is marked by the arrival of the visitor to the completed exhibition (Gouvêa de Sousa et al., 2002) (Figure 1 B).

Neither Gouvêa de Sousa et al. (2002) nor Simonneaux and Jacobi (1997) conceive explicitly of an intermediate phase between that of the scientific source knowledge and that of the exhibition, although Gouvêa de Sousa et al. (2002) imply the presence of such an intermediate stage by considering preparation and execution as two discrete moments. Indeed, in practice, exhibition engineering usually entails the formulation of a document or collection of documents, the curatorial brief (Nicks, 2002, p. 356), which spans the boundary between the context within which the scientific knowledge evolves and exists and the context within which a physical installation, namely the exhibition, is developed and implemented. The creation of such a document serves not only to extract a body of knowledge from the scientific field and reduce it to a content according to the exhibition objectives (Gouvêa de Sousa et al., 2002) but also to provide a guiding purpose (Nicks, 2002, p. 356) which informs the further creative work that is required during the implementation stage (Miles, 1988 , p. 43). The brief thus provides a means of translation between a scientific context and an exhibition context. In the present study, museographic transposition is conceptualised with a three-stage framework including the contexts of the scientific source knowledge, the curatorial brief, and the exhibition milieu (Figure $1 \mathrm{C}$ ).

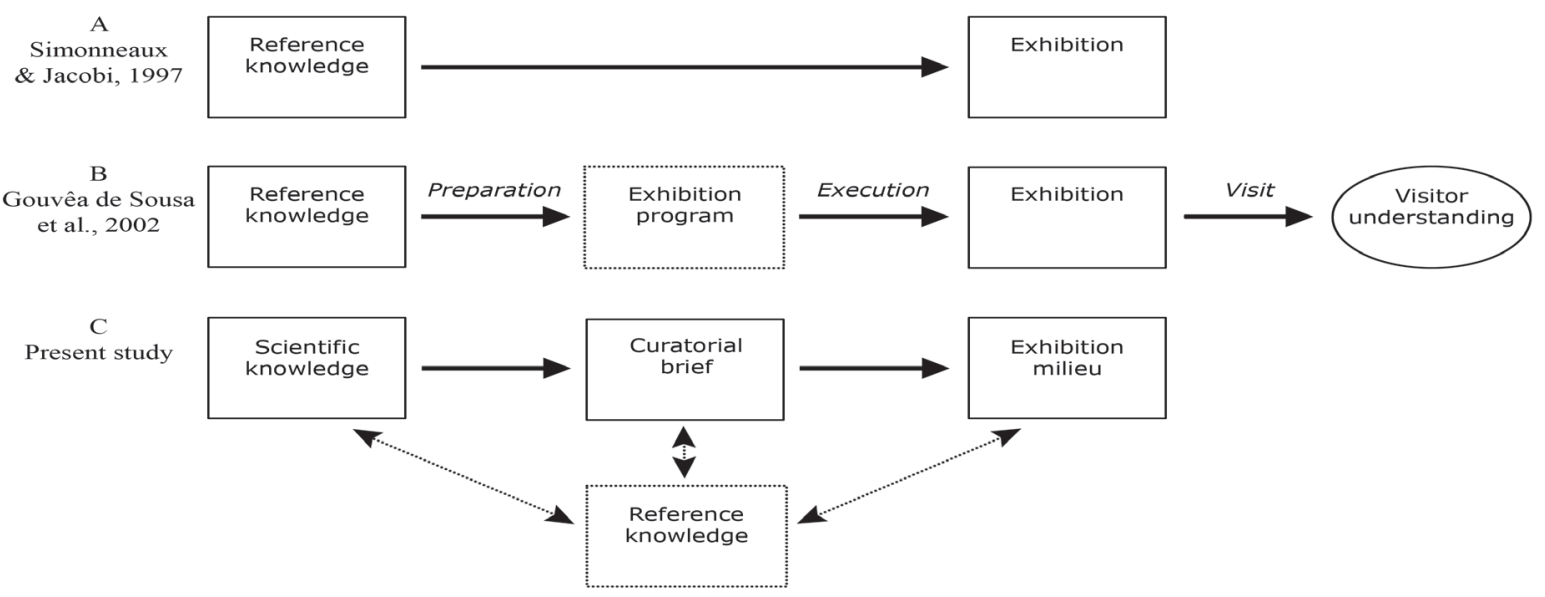

Figure $1^{1}$

The model of museographic transposition offers a structure for the analysis of the development and implementation of content in an exhibition, but does not in itself provide a theoretical context for this analysis. Simonneaux \& Jacobi (1997) used the model to carry out a linguistic analysis of the transposition of exhibition texts (Figure $1 \mathrm{~A}$ ), while Gouvêa de Sousa et al. (2002) used it to frame a semiotic exhibition analysis (Figure $1 \mathrm{~B}$ ). In both cases, the scientific source knowledge comprised the baseline against which the transposed version of the content was compared; hence the starting point of the transposition framework was in both instances designated as the reference knowledge (Figure $1 \mathrm{~A}$ and $\mathrm{B}$ ). In the present study, the notion of museographic transposi- tion is used to structure an epistemological analysis in which the changes following the deconstruction and reconstruction of a biological object of knowledge are mapped and analysed. Each step of the transposition is analysed in terms of the preceding steps as well as the current context; the reference knowledge may accordingly be thought of as an independent structure which encompasses not only the scientific knowledge in question, but also the context-related museographic permutations of it.

\section{Museographic Form}

The term museographic transposition has wider implications than just offering a model of the trans- 
formation of knowledge in an exhibition engineering context. While the modality of knowledge is the same in the scientific context and in the curatorial brief, namely text, the modality of the knowledge undergoes a change as it is transposed into the threedimensional installation of the exhibition milieu. The museographics of a subject accordingly deals with the material representation of a subject in a museum setting, i.e. the manner in which the subject is exhibited or its museographic form. Science museum exhibitions present scientific content, but inherent in the presentation is an indication of how the content is to be understood (Davallon, 1999, p. 7) and a comprehensive study of the knowledge present in the museum exhibition -the end product of museographic transposition -must consequently include an investigation of the museographic form in which that knowledge is presented. The present study employs the analytical framework regarding immersive exhibitions which was elaborated by Belaën (2003) on the basis of work by Montpetit (1996), and which is outlined in the following.

Immersion is a specialised exhibition practice in museums, defined by the creation of an illusion of time and place through the reconstruction of key characteristics of a reference world and by integrating the visitor in this reconstructed world (Bitgood, 1990). The successful reconstitution of the reference world relies on the presentation of the exhibition as a coherent whole with all the exhibited objects supporting the representation, the integration of the visitor as a component of the exhibit, and the consequent dramatisation of matter and message (Belaën, 2003) (Table 1).

\section{Logic of representation of the reference world.}

Belaën (2003) distinguishes three logics of representation: exogenous logic, endogenous logic, and a combination of the two. An immersive exhibition that is based on an exogenous logic represents a reference world which is real or fictional. The intent is to reconstitute this reference world as authentically as possible, and the rules or logic of this representation thus originate outside (exogenously to) the exhibition, in the existing reference world (Montpetit, 1996). An example of an immersive exhibit which represents a reference world according to an exoge- nous logic could be a walk-through tropical African rain forest with authentic animal and plant specimens or exact replicas of them. Here, the exhibition engineers are not free to interpret the subject matter, but must closely reconstitute the reference world.

If an immersive exhibit refers to a world that does not exist nor has existed, its mode of representation then follows an endogenous logic (Montpetit, 1996). The world represented in the immersive exhibit is created ad hoc to serve the needs of the exhibition objectives, and follows only the rules and logic which it itself generates (which are endogenous to it). An example of an exhibit which is based on an endogenous logic could be a virtual reality exhibit which creates a world for the user to explore according to the exhibition engineers' predefined rules. Here, the exhibition engineers have complete discretion over the creation of the represented world.

Finally, an immersive exhibition which employs a combination of exogenous and endogenous logics is an exhibition that utilises interpretation. If the reference world is not a human-scale realm, or if the significant experiences of the reference world are abstract, the exhibition engineers must rely on a metaphorical or analogical principle in order to represent that reference world (Montpetit, 1996). An example of an immersive exhibit based on a combination of logics could be a walk-through exhibit of a scale model of the human digestive tract. The morphology of such an exhibit would be based on the exogenous logic of an existing reference world (the human digestive tract) interpreted by exhibition engineers to create an ad hoc analogical representation according to an endogenous logic.

Integration of the visitor.

Physical space is not just the background to human activity and experience, but an intrinsic aspect of it (Hillier \& Tzortzi, 2006), and the spatial aspect of immersion exhibitions is thus central to the integration of the visitor. The integration of the visitor is due not only to their physical presence in the exhibit, but also to the implications of their body in the installation. These implications include the percep- 
tual experiences the visitor has during the visit and the role which is implicitly assigned to them in the proposed enactment. For this reason, if the exhibition does not invite the visitor to interact, the installation may be perceived as decoration and may not assume the full meaning necessary for the comprehension of the exhibition's message (Belaën, 2003).

The integration of the visitor may be based on a variety of techniques which offer more or less complete immersion. At one end of this range are exhibitions which simply reconstitute an authentic setting. Beyond creating an ambience, such exhibitions do not attempt to assign the visitor a role. An example of this level of visitor integration could be the aforementioned reconstruction of an African rainforest, open for visitor perusal and percolation.

Role-play is an intermediate form of visitor integration where the visitor is specifically assigned a role or character to play in an enactment. Belaën (2003) mentions as an example of such role-play the exhibition Titanic: the Artifact Exhibition, where visitors are given a replica of a White Star Line ticket bearing the name and history of an authentic passenger on the Titanic.

Finally, truly interactive exhibitions (rather than merely reactive exhibitions) allow the visitors to interact with and modify their environment in real time and thus offer a high level of visitor integration. An example could be the experience provided by a virtual reality walk on the bottom of the ocean, where events unfold according to the decisions acted out by the participant.

\section{Dramatisation of subject matter.}

Immersion exhibitions operate according to a principle of dramatisation, where the subject of the exhibition is apprehended by the visitor in terms of time and space (Belaën, 2003). The goal of any dramatisation is to make the audience perceive a narrative by displaying the actions of some characters in conflict. The characters'actions are organized in a plot, and the plot moves in a direction (Damiano, Lombardo, \& Pizzo, 2005). Accordingly, the degree to which the subject of an immersive exhibition may be dramatised depends on the degree to which the museum visitor understands and accepts their role as the main character, the degree to which the conflicts of that character are made clear to them, the degree to which the surroundings allow them to act on that conflict, and the degree to which they are able to make sense of these actions in terms of a direction. Some types of immersive exhibitions depend strongly upon this principle of dramatisation (for example, a virtual reality experience), while others rely less on it (for example, a reconstituted African rain forest).

In sum, the analysis of the museographic transposition presented in the following sections will consider an object of knowledge and its moments of transformation between the scientific context, the curatorial brief, and the exhibition milieu. Further, the analysis will account for the museographic form of the knowledge in the exhibition milieu, specifically the components of an immersion exhibit: logic of representation, integration of visitor, and dramatisation of subject matter (Table 1).

\begin{tabular}{|l|l|}
\hline \multicolumn{1}{|c|}{ Characteristics of an immersion exhibit } & \multicolumn{1}{c|}{ Subcategories } \\
\hline \multirow{4}{*}{ Logic of representation of the reference world } & Exogenous \\
\cline { 2 - 2 } & Endogenous \\
\cline { 2 - 2 } Integration of visitor & Combination of exogenous and endogenous \\
\hline \multirow{4}{*}{ Dramatisation of subject matter } & Ambience \\
\cline { 2 - 2 } & Role-play \\
\cline { 2 - 2 } & Real time modification of environment \\
\hline & Visitor accepts the role of a character \\
\cline { 2 - 2 } & Visitor understands the conflicts of character \\
\cline { 2 - 2 } & Exhibit allows visitor to act on conflicts \\
\cline { 2 - 2 } & Visitor makes sense of actions in terms of direction of plot \\
\hline
\end{tabular}




\section{Empirical Setting, Data, and Method of Analysis}

\section{Setting}

The case used to exemplify this theoretical framework was part of the exhibition Xtreme Expedition which opened in 2007 at the Danish science centre Experimentarium in Copenhagen. Xtreme Expedition was the result of collaboration between three institutions: Experimentarium, the Royal Belgian Institute of Natural Sciences (RBINS) in Belgium, and Naturalis in the Netherlands. The general theme of Xtreme Expedition was adaptations to extreme environmental conditions on Earth and it featured five clusters featuring heat, cold, aridity, low oxygen, and darkness, respectively. The attention here was to the engineering of a single immersive exhibit, Cave Expedition, within the cluster on darkness. The stated objective of Xtreme Expedition was to enable visitors to "find out how animals, microbes and plants are adapted to survive under stressful conditions" (Executive Committee, 2005b, p. 4), and extrapolating the objective to the exhibit level, the goal of Cave Expedition may be expressed as enabling the visitor to find out how the cave beetle is adapted to its environment of permanently dark caves.

\section{Materials}

The object of knowledge the adaptations of the blind cave beetle to its environment of permanently dark caves was studied in the three contexts: the scientific discourse, the curatorial brief, and the exhibition milieu, respectively. For the context of the scientific discourse, scientific journals and text books on cave fauna and carabid beetles in general and darkness-adapted beetles in particular were examined.
Furthermore, the curator of beetles at the Natural History Museum of Denmark was consulted.

The curatorial brief consisted of the document Xtremes: storyline for an exhibition about adaptations to extreme environmental conditions on Earth, the purpose of which was to present the conceptual framework of the exhibition and translate it into exhibition design (Executive Committee, 2005b). A preliminary document Xtremes: final content analysis (Executive Committee, 2005a) also created by exhibition engineering staff, was included in the study. This document did not consider the museography of the exhibition theme, but dealt exclusively with the scientific content. The latter document was annotated, and the references contained therein were included in the scientific literature examined.

Finally, the exhibition milieu studied was the immersive exhibition unit Cave Expedition which consisted of three panels and an artificial cave (Figure 2). The cave consisted of a darkened scented passageway with nine animal models: four lizards, three spiders, and two frogs mounted on the wall. The models were to scale, i.e. $5-15 \mathrm{~cm}$ long. Panel 1 , located approximately $2 \mathrm{~m}$ to the right of the entrance to the cave, carried a short text about the blind cave beetle, an illustration of five carabid beetles sequenced according to increasing degree of adaptation to living underground (Figure 3), and a preserved specimen of Aphaenops cerberus, a blind cave beetle, with a distribution map. Panel 2 was located at the entrance to the artificial cave and carried text instructions to the visitors about how to interact with the exhibition unit. Panel 3 was located immediately outside the exit of the cave and carried text instructions to the visitors about how to use the adjacent score board. This score board carried replicas of the animal models and sources of scents found inside the cave, each equipped with a button which fed back to a single digital display. 


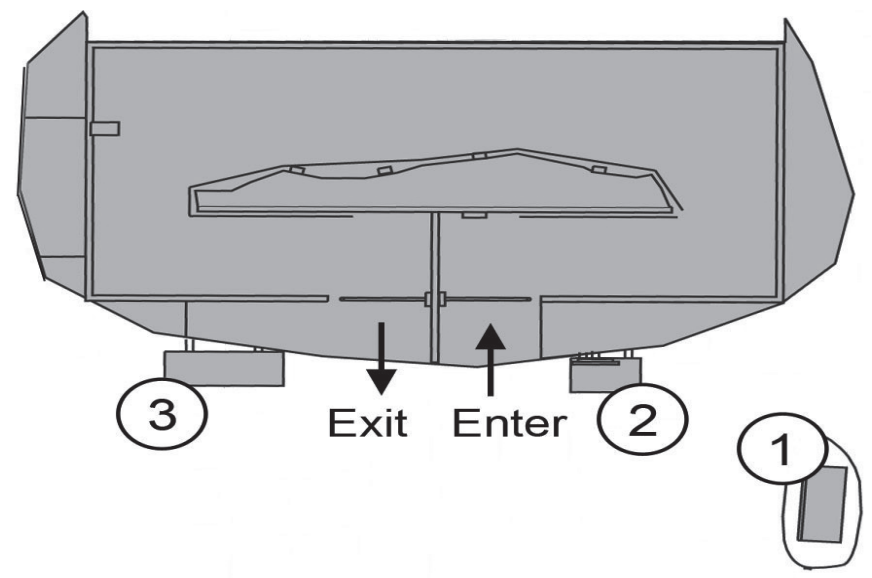

Figure $2^{3}$
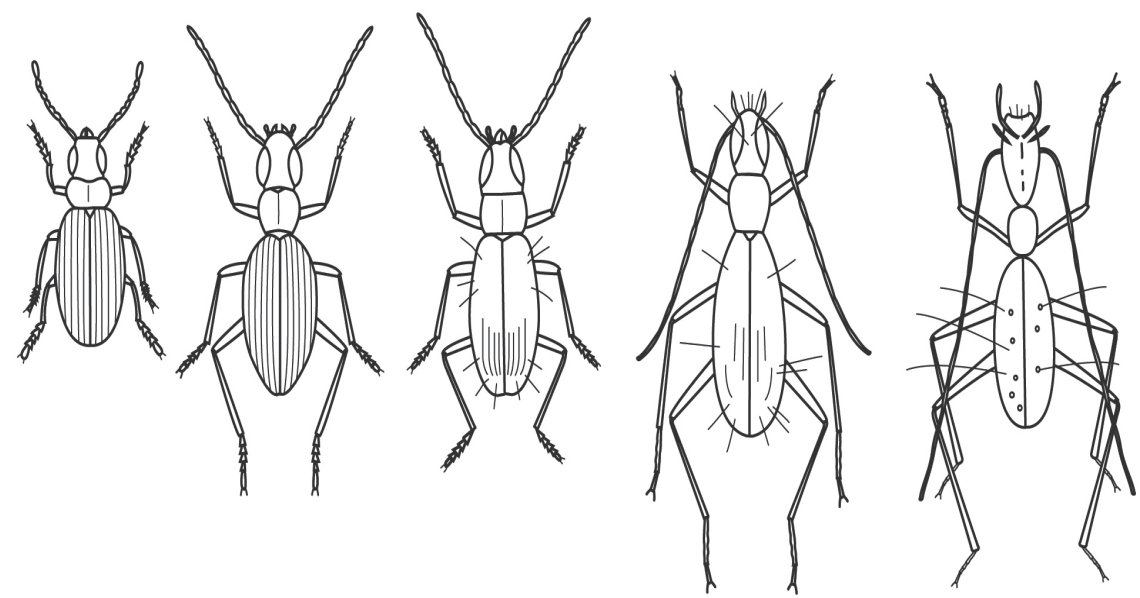

Figure $3^{4}$

\section{Informants}

The study of the tangible components of the museographic transposition - the scientific literature, the curatorial brief, and the exhibition unit - was informed by open-ended interviews with four selected exhibition engineers involved in the exhibition development. The curatorial brief and the preliminary document mentioned in the preceding section were used in the interviews as conceptual milestones in the transposition process; these documents were used by the interviewer as evidence of the status of the transposition at different stages and as prompts to the exhibition engineers'memories of past events, helping them to avoid post hoc rationalisations of their past actions.
Two of the interviewed exhibition engineers were employed at Experimentarium (in the following they are designated as EE1 and EE2); two were employed at RBINS (in the following they are designated as EE3 and EE4). The exhibition engineer responsible for Naturalis' contribution to the exhibition was no longer employed there; thus there were no informants from the Netherlands. Three exhibition engineers were interviewed separately, and one, EE4, was interviewed in the presence of EE3. The interviews lasted for one to two hours and were audio recorded and later transcribed. The interviews at Experimentarium took place in November, 2007, where the first half-hour of the interviews at Experimentarium took place at the exhibit itself. The interviews at RBINS took place in April, 2008; the exhibit had not yet been moved to RBINS at this time, so the interviews took place in an office. 


\section{Procedure}

In order to map the changes in the structure of the object of knowledge the adaptations of the blind cave beetle to its environment of permanently dark caves through the phases of museographic transposition, it was necessary to understand the context and modality of the knowledge present in each stage of the transposition. For example, the knowledge contained in the scientific discourse was in a written form and readily defined, whereas the knowledge contained in the exhibition milieu was embodied in text panels, objects, and other three-dimensional installations and was accordingly defined partly through inference.

Knowledge in the scientific context.

The scientific study of animal adaptations entails an analysis of the environment of the species in question and an examination of the morphological, physiological, and behavioural traits of that species which may improve its ability to interact with its environment and thus may be categorised as adaptive (cf. Culver, 1982). From the perspective of the scientific discourse, the theme of animal adaptations accordingly spans several domains of knowledge (e.g. biology, chemistry, geophysics) as well as several subdomains (e.g. ecology, physiology, behaviour). Furthermore, animal adaptations are in a sense immaterial because they consist of both a structure and a function and consequently only manifest themselves in interaction with the environment. These characteristics make the theme of an animal's adaptations to its environment difficult to describe within a general epistemological model of biological knowledge. Here, a concept map is used to structure the object of knowledge the adaptations of the blind cave beetle to its environment of permanently dark caves in the scientific context.

Concept maps graphically organise and represent knowledge by connecting single knowledge units, or concepts, with one another using linking words or phrases (Novak \& Cañas, 2008). Such links may connect concepts located in different domains of knowledge and are thus able to capture the relationship between, for example, a given feature of the environment and the corresponding adaptive trait of an animal. Furthermore, concept maps may include several domains of knowledge and can thus encompass objects of knowledge that span multiple disciplines.

On the basis of a survey of scientific journal articles and textbooks, a text was constructed describing the blind cave beetle's adaptations to its environment of permanently dark caves. This text was reviewed for scientific accuracy by the curator of beetles at the Natural History Museum of Denmark and finally summarised in the form of a concept map (Figure 4) hereafter designated as the scientific knowledge.

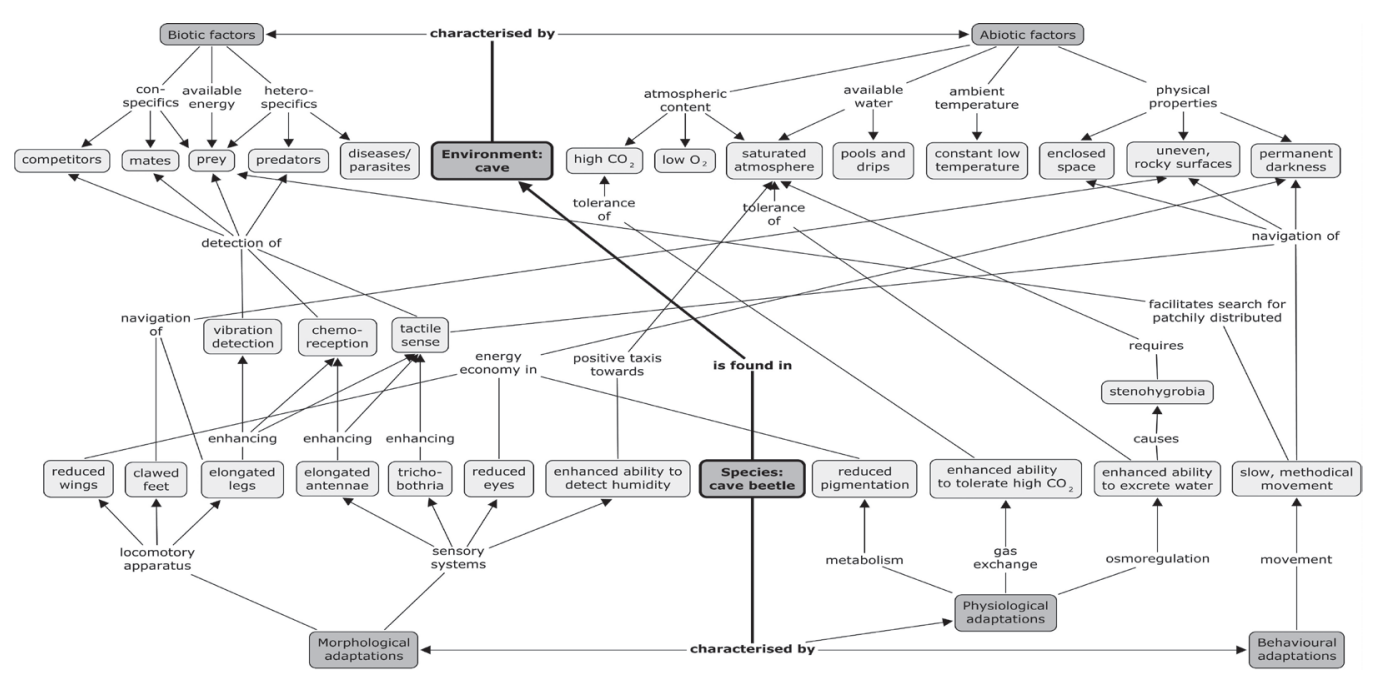

Figure $4^{5}$ 
Knowledge in the curatorial brief context.

The curatorial brief included a summary of the scientific content and a brief description of the proposed exhibit on the blind cave beetle and its adaptations to darkness (Table 2). The exhibit was described in the text as consisting of two subunits, a specimen-based display of three beetle species and an experience-based subunit comprising an orientation route for visitors. The text summarising the scientific content and describing the proposed exhibit subunits was analysed in terms of the concepts defined in the scientific knowledge as exemplified in the following excerpt from the curatorial brief:

\section{Beetles that live in caves generally have longer legs and antennae Cave beetle (organism)

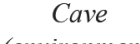 \\ (environment)}

than closely related species that live above the ground. The legs and antennae
Elongated
legs $\begin{gathered}\text { Elongated } \\ \text { antennae }\end{gathered}$

\begin{tabular}{l|l|}
\hline Scientific content & Description of proposed exhibition unit \\
\hline $\begin{array}{l}\text { Cave beetle (Duvalius stankovitchi) } \\
\text { Beetles that live in caves generally have longer legs and antennae } \\
\text { than closely related species that live above the ground. The legs } \\
\text { and antennae are used for orientation by touch (compare with a } \\
\text { blind man's walking stick). }\end{array}$ & $\begin{array}{l}\text { Orientation route in the dark for visitors, using a stick for } \\
\text { orientation. }\end{array}$ \\
\hline $\begin{array}{l}\text { Three coleopteran species of the Trechinae group in the genus } \\
\text { Duvalius, from different habitats, have different body size and } \\
\text { antennae size. }\end{array}$ & \\
The Duvalius procerus species live in the alpine zone. They have \\
eyes and a massive body with short legs and antennae. \\
The species Duvalius subterraneus lives under stones buried in \\
woods. It has reduced eyes, a longer body and longer antennae \\
than the former species. \\
$\begin{array}{l}\text { The species Duvalius stankovitchi lives in caves. It is totally } \\
\text { blind, depigmentated, with a longer body and antennae, and } \\
\text { more pubescences ("hairs") than the former two species. }\end{array}$ & $\begin{array}{l}\text { Specimen of Duvalius procerus, Duvalius subterraneus, Duvalius } \\
\text { stank They are small: 5-7 mm. }\end{array}$ \\
\end{tabular}

Table $2^{6}$

The presence of other concepts in the curatorial brief had to be inferred. Consider the description of the experience-based subunit as an "orientation route in the dark for visitors". The objective of this orientation route was to give the visitor the experience of being a cave beetle by putting the visitor in the place of the animal (EE1). Accordingly, it was inferred that visitors would experience transient loss of vision when entering the darkened orientation route, and that this transient sightlessness was an analogy to the 
cave beetle's adaptation of having reduced eyes. The concept of "reduced eyes" was thus included in the concept map of the knowledge present in the curatorial brief (Figure 5).

Knowledge in the exhibition milieu.

The exhibition milieu of the Cave Expedition exhibit consisted of text, illustrations, models, scent, a walk-through artificial cave, an interactive score board, and a specimen. As in the case of the curatorial brief, the reference knowledge was used as the basis with which to map the elements of knowledge which were present in the exhibition context. An example of this analysis is offered by the illustration on Panel 1 of the exhibition unit (Figure 3). Discernable from the comparison of the five carabid beetles are the following characteristics of cave beetles: elongated legs, elongated antennae, trichobothria (the presence of sensory hairs), clawed feet, and in one case, reduced eyes. These concepts were therefore included in the concept map of the exhibition milieu.

Several elements of knowledge were present only implicitly as features of the immersion experience, and consequently only became tangible through interpretation of the immersive exhibit form. For example, the presence of models of lizards, frogs, and spiders inside the artificial cave may be construed in a number of ways, but only through the understanding of the exhibit as an immersive experience where the visitor takes on the role of the cave beetle, do the animal models assume their intended meaning: that of cave beetle heterospecifics, and more specifically, that of cave beetle predators (EE1). The presence of these animal models was thus interpreted as the concept of heterospecific predators and included in the concept map of the exhibition milieu.

\section{Results}

\section{The First Moment of Transformation}

The purpose of the curatorial brief was to extract a body of knowledge regarding the adaptations of the blind cave beetle to its environment of permanently dark caves from the scientific field and reduce it to a content from the viewpoint of the exhibition objective: to enable visitors to "find out how animals, microbes and plants are adapted to survive under stressful conditions" (Executive Committee, 2005b, p. 5). The transposition of the object of knowledge to the curatorial brief context involved a division of the knowledge into proposals for two subunits: a proposal for a specimen-based subunit and a proposal for an experience-based subunit (Table 2). The transposition entailed a reduction in the complexity of the object of knowledge: of the 28 concepts that formed the structure of the knowledge in the preceding step, the scientific context, 9 were present in the curatorial brief context.

The specimen-based subunit was considered by the exhibition engineers to be a concession to the museal tradition of exhibiting specimens (EE3). The partners finally included the specimen-based subunit in the curatorial brief due to the perceived illustrative value of the specimens: "because what the cave beetle does with its long antennae and its long legs - that's what the humans do in the cave exhibition: finding their way" (EE3). The specimen-based subunit thus provided the background knowledge for the visitor to subsequently play the role of the beetle in the experience-based subunit (EE1). The proposal for the specimen-based subunit included the display of three beetles, namely Duvalius procerus which lives above ground, D. subterraneus which lives under stones, and D. stankovitchi which is a blind cave beetle and lives in permanently dark caves. Discernable from the comparison of these three species were four concepts, namely those of the cave beetle as being blind (having reduced eyes), being depigmentated, having elongated antennae, and having more sensory hairs (trichobothria) than its above-ground counterparts.

The main objective of the experience-based subunit of Cave Expedition was to give the visitor the experience of being a cave beetle by putting the visitor in the place of the animal (EE1) and "activating [in the visitor] the senses which darkness-adapted animals rely on and navigate by" (EE2). The transposition of the object of knowledge the adaptations of the blind cave beetle to its environment of permanently dark caves towards this goal was accordingly centred on the beetle's elongated legs and antennae, which provide it with excellent chemoreception and mechanoreception 
abilities. The curatorial brief proposed the construction of an orientation route in the dark (the cave) through which the visitor (the beetle) could navigate with a blind person's cane (elongated antennae). The cane may be thought of as a temporary morphological adaptation in the visitor providing tactile experiences, whereas the idea of chemoreception is not mentioned further in the curatorial brief.

The proposed subunit indirectly induces in the visitor another cave beetle sensory feature, namely that of reduced eyes. The visitor, of course, does not experience the morphological adaptation of reduced eyes, but the sightlessness that is brought about by the darkness of the proposed visitor orientation route can be described as a temporary behavioural analogue to the cave beetle's permanent blindness. The darkness also induces slow, systematic movement in the visitor, who without the use of vision is forced to feel their way through the cave.

In summary, of the concepts present in the scientific context, a total of nine were transposed to the curatorial brief, namely those of a cave as an enclosed, darkened space and the blind cave beetle as being depigmentated and as having sensory hairs, elongated legs and antennae which enhance its tactile sense, and which, together with the slow methodical movement induced by the surroundings, enhance its ability to navigate its environment (Figure 5).

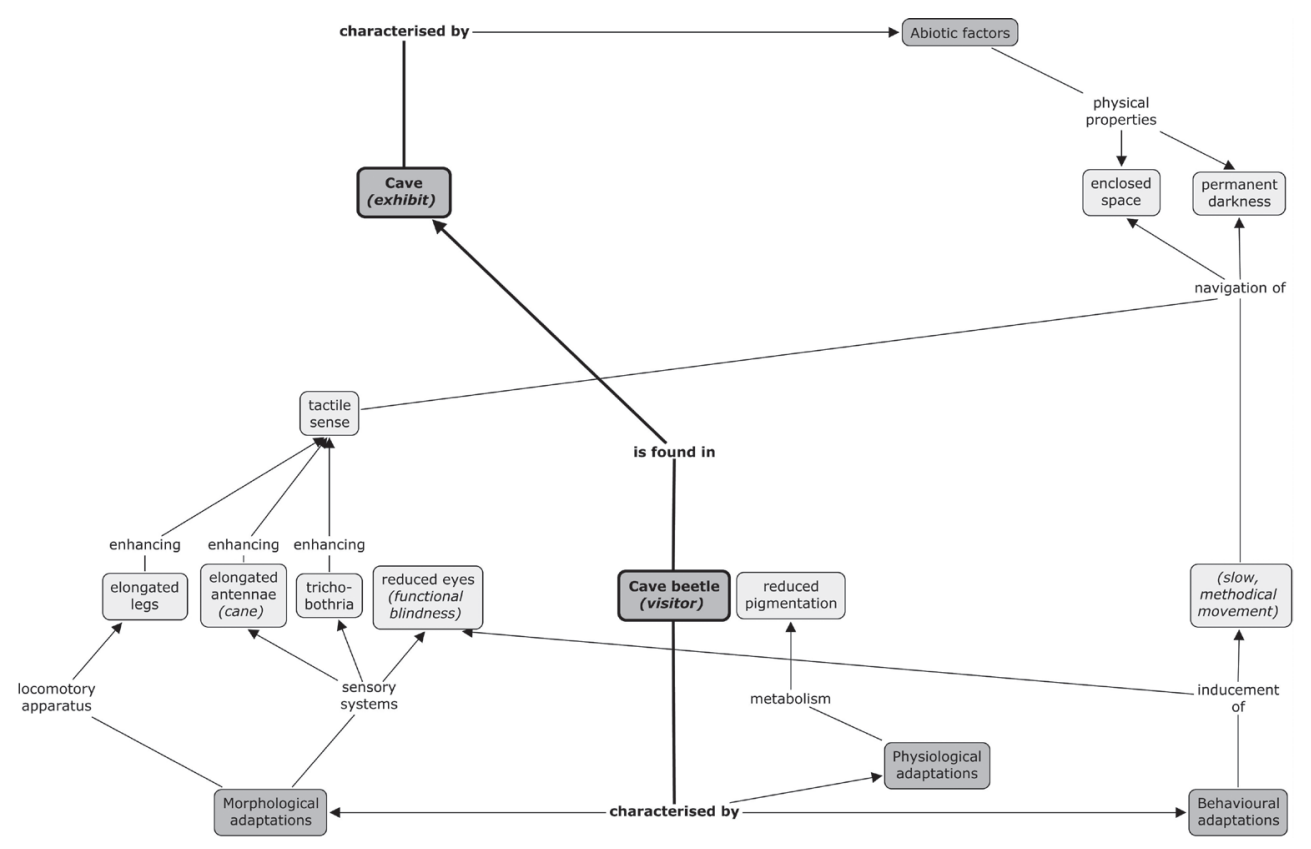

Figure $5^{7}$

\section{The Second Moment of Transformation}

The curatorial brief provided the exhibition engineers with content and purpose, leaving room for the creative reconstruction of the object of knowledge the adaptations of the blind cave beetle to its environment of permanently dark caves in the transposition from the curatorial brief context to the exhibition milieu. This creative reconstruction is evidenced by an increase in the complexity of the object of knowledge: of the nine concepts that structured the object of knowledge the adaptations of the blind cave beetle to its environment of permanently dark caves in the curatorial brief, eight were transposed into the exhibition milieu and an additional six concepts were added.

The number of specimens in the specimen-based subunit was reduced from the three proposed in the curatorial brief to just one actually displayed specimen, Aphaenops cerberus. RBINS staff, who were responsible for the specimens exhibited in Xtreme Expedition, were unable to locate three comparable beetle specimens 
that could be displayed for the duration of the exhibition, and the substitution of the planned three specimens with the one specimen and the illustration of five beetles (Figure 3) was thus a case of "small details disturbing the beautiful plans - a well-known phenomenon in exhibition preparation!" (EE3).

In spite of this constraint, the specimen-based subunit included the concepts of the cave beetle having the following morphological adaptations: clawed feet, elongated legs and antennae, trichobothria, and reduced eyes. The elongated legs and antennae enhance the animal's chemoreceptive abilities, and the legs, antennae and sensory hairs enhance its tactile sense. These enhancements enable the beetle to detect its prey and to navigate its environment, which is permanently dark. The specimen subunit thus includes nine concepts, three of which (elongated antennae, trichobothria, and reduced eyes) can be traced from the curatorial brief and six of which (clawed feet, elongated legs, enhanced tactile sense and chemoreception, prey, and darkness) originate in the scientific context (Figure 6).

The experience-based subunit is founded on an immersion principle, where an illusion of time and place is created through the reconstruction of key characteristics of the cave beetle's life history and habitat; and through the integration of the visitor into this reconstructed world. The reconstructed world is based on an interpretation where the reference world, the cave beetle's habitat, is represented as a scale model. The experience-based subunit accordingly relies on a principle of analogy to mediate its message, namely the analogies of the exhibit being the cave beetle habitat, the visitor being the cave beetle and the visitor's experiences being those of the cave beetle. It is based on an exogenous logic, i.e. a reference world that actually exists (the cave beetle's life history and habitat) combined with an endogenous logic, i.e. a world that is created in conjunction with the exhibition (the analogical representation of the reference world).

\section{Representation of the reference world: the artificial} cave.

The exhibition milieu representing the cave beetle habitat consists of an expansion of the curatorial brief's concept of an enclosed, darkened passageway with the concepts of uneven, rocklike surfaces and the presence of heterospecific predators (animal models) and a source of scent. The curatorial brief described the physical structure of the experiencebased subunit simply as a darkened orientation route. Yet, the completed subunit has irregular, rock-like surfaces that somewhat reflect the physical properties of the cave beetle's natural cave environment as described in the scientific context. Did the concept of the cave interior in fact originate in the scientific context? Howarth (1983) describes the morphology of the cave beetle habitat as an "interconnected network of spaces $[\ldots]$ which range from over $1 \mathrm{~mm}$ to about $20 \mathrm{~mm}$ in width". The $5 \mathrm{~mm}$ cave beetle thus experiences variations in the rock structure of its cave habitat ranging from $20 \%$ to $400 \%$ of its own body length. A model of the cave beetle habitat scaled up to human size would thus consist of spaces ranging in width from 35 to $700 \mathrm{~cm}$. In fact, the width of the passageway of the experience-based subunit varies on a much smaller scale, with a difference of less than $30 \mathrm{~cm}$ between the widest and narrowest points, corresponding more realistically to the characteristics of a man-made tunnel through rock.

The animal models (four lizards, three spiders, and two frogs) in the passageway of the artificial cave were explained differently by the exhibition engineers from Experimentarium and RBINS, respectively. The models were perceived by one Experimentarium exhibition engineer as a natural choice of heterospecific species in that they reflected what could be found in natural caves (EE2). The other Experimentarium exhibition engineer elaborated "These are the types of animals you'd find in caves. These are animals that would prey on the beetles [in the wild]" but goes on to say:

It's also a practical consideration: which animal [models] were available at the toy store and how durable were they. [...] And [the visitors] must to be able to feel the difference between them. Basically, this exhibition unit is an exercise in feeling and remembering.

One RBINS exhibition engineer agreed with this viewpoint, stating that the animal models were chosen because they were easy for the visitors to iden- 
tify by touch, but questioned the idea of the chosen species as being representative of cave beetle predators or heterospecifics (EE3). This exhibition engineer went on to clarify that the dependence on the sun of herpetiles such as lizards and frogs precludes them from inhabiting permanently dark caves, but that there do exist darkness-adapted spiders that prey on cave beetles.

Integration of the visitor: the role of the cave beetle.

The stated intent of the experience-based subunit was to put the visitor in the place of the cave beetle, physically placing the visitor in the artificial cave and producing by way of analogy an experience for the visitor of the cave beetle's adaptations and its resulting experience of its surroundings. The visitor is introduced to the role of being the cave beetle by the text on Panel 2 (Figure 2) which reads "Enter the cave. Use your hands and nose to search for animals and scents along the cave wall". This text refers back to the text on Panel 1 (Figure 2) of the specimen-based subunit, which reads "The blind cave beetle feels, smells, and tastes its way through the dark. [...]". The analogies are thus presented between the tactile sense of the visitor and the beetle, and between the chemoreceptive sense of the visitor and the beetle (Figure 6).

The idea of providing the visitors with canes for navigating the darkened passageway as an analogy to the cave beetle's morphological adaptation of elongated limbs was not realised in the experience-based subunit. One exhibition engineer explained that visitors' effective use of canes in the darkness would require both some practice and some physical space, and that due to constraints on both of these commodities it was decided to abandon the idea (EE3). Thus, the recruitment of the visitors' tactile sense is mapped as a behavioural rather than a morphological adaptation (Figure 6).

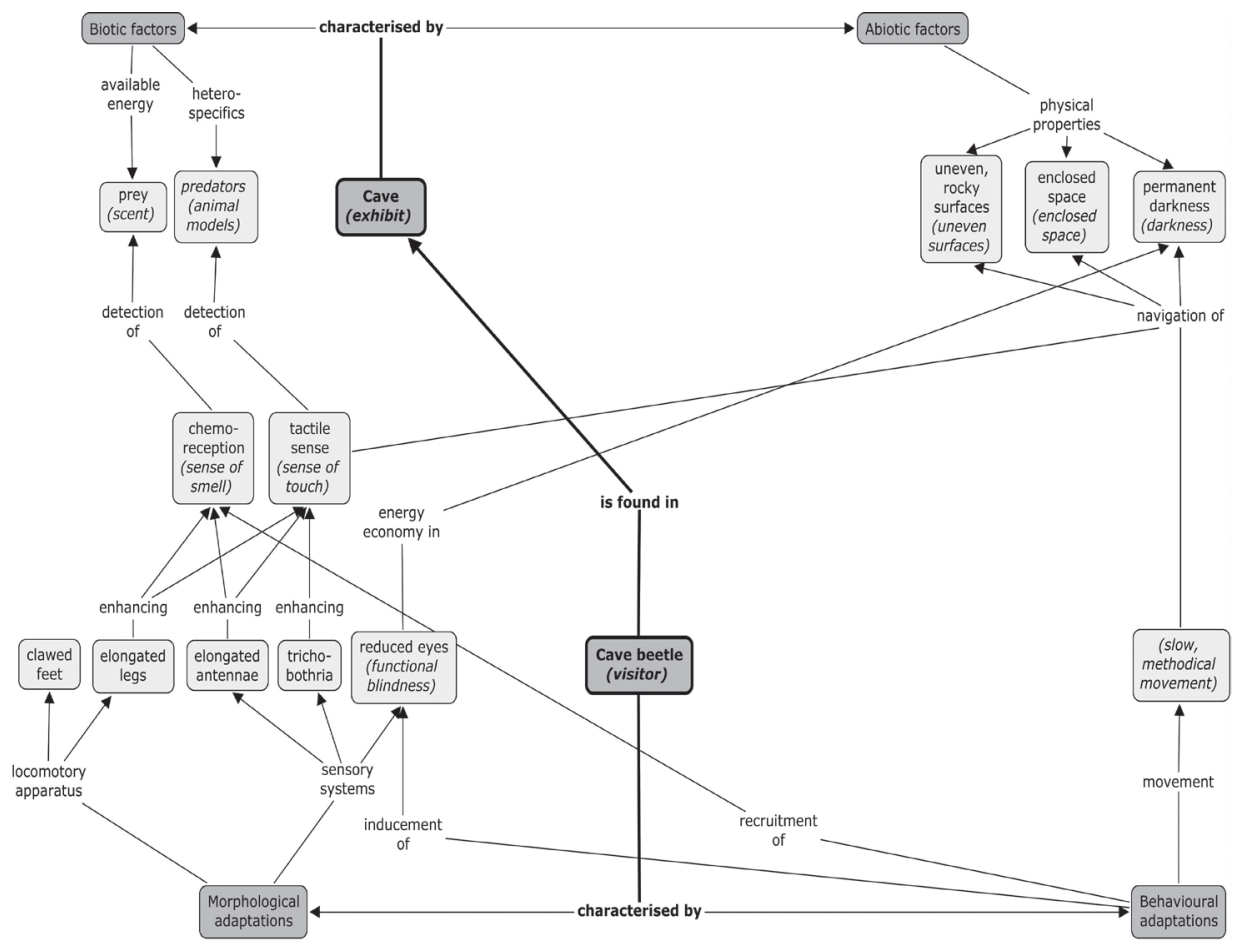

Figure $6^{8}$ 
The concept of chemoreception is not mentioned in the curatorial brief, and even though chemoreception is a crucial sensory channel for insects (Kershaw, 1988, p. 143), the re-entrance of the concept of chemoreception via the presence of scents in the exhibition milieu is not explicitly derived from the scientific knowledge. Instead, chemoreception or the sense of smell is consistently mentioned by the exhibition engineers as being just one of several sensory channels available to humans in the dark (EE3, EE2), referring to capacities of the visitor rather than of the beetle. When asked for the reason the scents were included in the exhibition subunit, one exhibition engineer stated "I believe that the more senses we can make people employ, the wider we can open the door to their minds" (EE1).

\section{Dramatisation of the subject matter: the cave beetle's experiences.}

The experience-based subunit operates according to a principle of dramatisation. The main character of the drama is that of the cave beetle, which role the visitor is induced into playing. The visitor is thus both audience and participant in the narrative. The conflict of the main character is that of inhabiting the cave environment, and the character's actions: navigating the dark cave environment, locating and successfully identifying the animal models (which represent cave beetle predators) and identifying scents (which represent cave beetle sources of food) accordingly comprise the plot of the narrative. The plot moves in the direction of the cave beetle's orientation in and navigation of its habitat, which for the visitor corresponds to a successful circuit of the cave environment. The visitor enters the artificial cave through a clearly marked entrance; this entrance is situated immediately next to the clearly marked exit. The physical beginning and end of the walk-through tunnel thus also mark the beginning and end of the narrative, and consequently provide the visitor with additional navigational and narrative direction.

On entering the cave, the visitor is rendered functionally sightless (reduced eyes) by the darkness of the artificial cave, and must accordingly slowly and methodically navigate the darkened passageway using their tactile sense. The spatial layout of the artificial cave -that of a tunnel -effectively dictates the direction of movement towards the exit, and the presence of a scent induces the visitor to use their sense of smell during the circuit of the cave.

In total, the exhibition milieu includes five (darkness, enclosed space, tactile sense, reduced eyes, and slow methodical movement) of the seven concepts present in the curatorial brief and three (predators, chemoreception, and uneven, rocky surfaces) which were present in the scientific knowledge (Figure 6).

\section{Synthesis of Descriptive Model}

In the following, the results will be synthesised into a descriptive model that accounts for the two moments of transformation as well as the status of the object of knowledge in each of the three transposition contexts: the scientific context, the curatorial brief, and the exhibition milieu.

The creation of the curatorial brief marks the intersection between the scientific source knowledge and the particulars of the museographic form. Each element of knowledge that figures in the curatorial brief ideally serves the dual role of representing an aspect of the scientific knowledge and constituting a part of the support for the intended visitor experience. It is therefore not surprising that the creation of the curatorial brief involves a reduction of the elements of scientific knowledge, as not all elements of knowledge are equally suited to serving this dual role. From the vantage point of the scientific context, the process towards the curatorial brief may be seen as an epistemological development, while from a museographic perspective, the process may be seen as a museum-pedagogical development which considers the non-content-related particulars of the exhibit form -here, the component parts of an immersion exhibit.

Once developed, the curatorial brief serves as a focus for the second moment of transformation: the execution of the exhibition milieu. The creative interpretation by the exhibition engineers of each of the elements in the curatorial brief combines to form the exhibition milieu, a three-dimensional installation the purpose of which is to provide the visitor with an intended experience. 


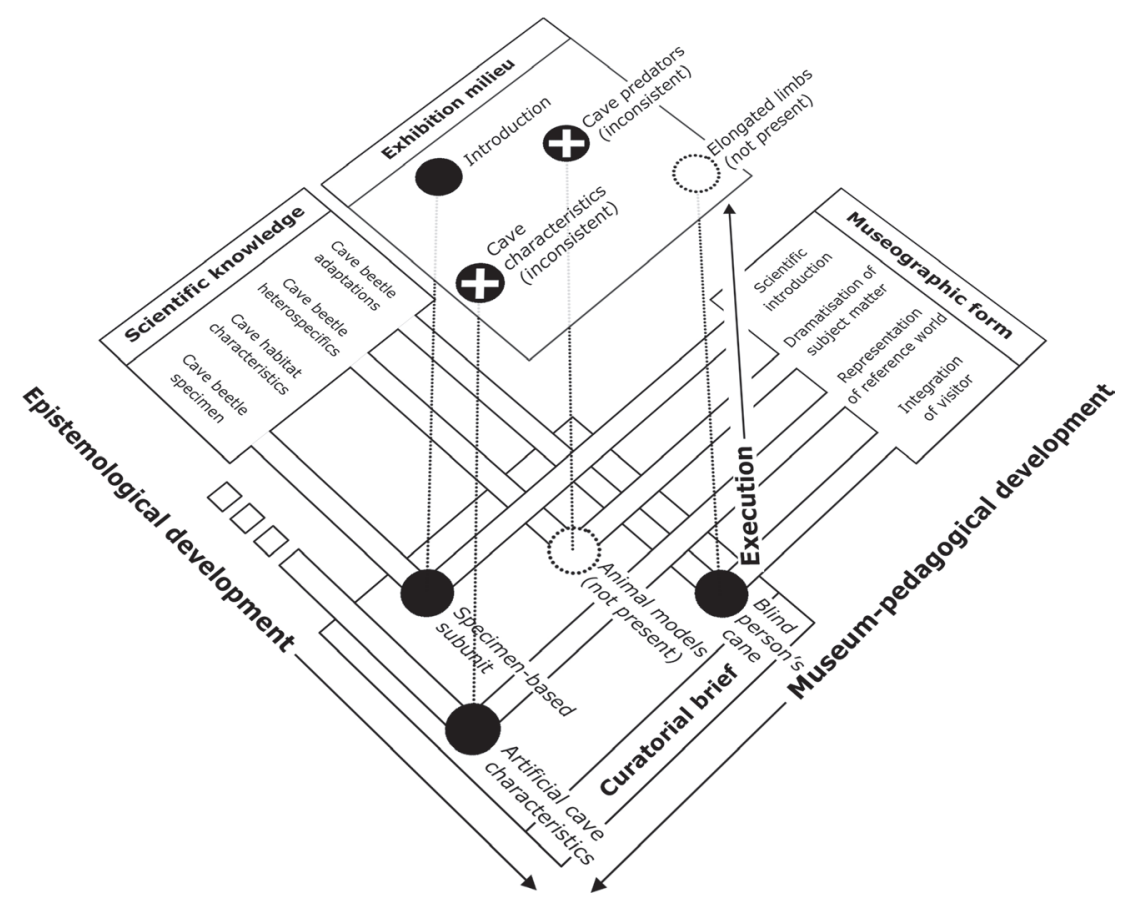

Figure $7^{9}$

According to this model of exhibition engineering, the integrity of the exhibition milieu -the degree to which the implemented exhibit forms a coherent whole -is a function of the consistency of the museographic transposition of its component parts. Ideally, each of these component parts should grow from the intersection between a specific element of scientific knowledge and a specific element of the museographic form as illustrated in the model (Figure 7). Where a component is not consistently supported by both scientific knowledge and museographic form, the component in question runs the risk of compromising the integrity of the exhibition milieu.

Our attention may now be directed back towards the research question, namely: what is the nature of the constraints and opportunities which govern the putting-into-exhibition of a specific object of knowledge? According to the presented model, the main constraint on the process of exhibiting an object of knowledge is reconciling the pertinent elements of the scientific knowledge with the particulars of the museographic form. In other words, the chosen exhibit type or genre has real constraints as to how a scientific object of knowledge can be transposed into a didactic object. But conversely, in a more positive view, the museographic form may also be seen as the lens through which a scientific object of knowledge can be viewed in order to achieve a consistent transposition of it. In this sense, the choice of museographic form offers the exhibition engineers genuine (and perhaps new) opportunities as to which aspects of an object of scientific knowledge they wish to emphasise, although choosing this emphasis requires a thorough understanding of the specificities of the chosen museographic form and their implications. In sum, the first moment of transformation in museographic transposition is governed by a dialectic relationship between scientific knowledge and museographic form.

According to the model, the second moment of transformation or execution is influenced by more practical considerations. The execution phase, being one step removed from the context of the scientific knowledge, is marked by a relaxation of epistemological vigilance which allows for the introduction of concepts originating from outside the transposition process. This relaxation of epistemological vigilance, then, may undermine the integrity of the exhibit in spite of the fact that the introduction of these concepts signifies an attempt to create exactly that: a coherent 
exhibit. In sum, the second moment of transformation is under less rigid epistemological control and thus subject to external influences such as the alternative scientific conceptions of exhibition engineers.

\section{Discussion}

The museographic transposition that took place in the development of the exhibit Cave Exhibition was shaped by constraints and opportunities related to the particulars of the scientific knowledge, the particulars of the museographic form, and external influences. The following sections first discuss the limitations of this study and its findings, then provide select examples of components of Cave Expedition that have been transposed with varying degrees of consistency, the resulting contributions of these component parts to the integrity of the exhibition milieu, and finally, some perspectives on the implications of the findings.

\section{Limitations of this Study}

The analysis of museographic transposition was based on tangible sources, such as documents and the exhibit itself as well as intangible sources, namely the four exhibition engineers' recollections of the process of exhibit development. Using the exhibition engineers' recollections as evidence of the transposition process rather than studying the process in real time raises some issues of validity, simply because the exhibition engineers may have had difficulty remembering in detail the content of their past discussions and negotiations. As a consequence, the exhibition engineers may have provided the interviewer with accounts that reflected their post hoc rationalisations of the exhibit development process rather than reconstructing the events that actually took place. Using the exhibit planning documents as a point of departure for the interview questions was one way of fixing some of the actual events in time and place; another was physically situating the interviews at the exhibit itself, as was the case in Experimentarium. Ideally, a study of museographic transposition would follow the discussions and negotiations of exhibition engineers in situ (e.g. Macdonald, 2002); however, the advantage of acquiring such data should be weighed against the relatively long period of time in which the process of full-time museum exhibition planning and implementation takes place (20 months in the case reported in Macdonald, 2002).

\section{Example 1: The Display of Specimens}

The three collaborators Naturalis, RBINS, and Experimentarium had different approaches to exhibition engineering, deeply rooted in the characteristics of their respective institutions. The difference in approaches was acknowledged by the respective exhibition engineers who cited the potential for crossfertilisation as the reason the collaboration had been undertaken in the first place (EE1, EE2, EE3), but it was also evident in many of the decisions made during the exhibition engineering process. Naturalis adhered strongly to the scientific content which was to be exhibited and preferred to develop this content extensively prior to any consideration of the exhibition form. In contrast, Experimentarium perceived visitor considerations as the most important criterion in selecting the scientific content to be displayed. RBINS placed itself between these two positions, "understanding the excellent reasons of both" (EE3).

The difference in institutional approaches to exhibition engineering illustrates the use of the model of exhibition engineering (Figure 7). When deciding whether to exhibit the cave beetle specimens, the staff of RBINS and Naturalis, adhering to their traditional role of collecting and exhibiting specimens (cf. Doering, 1999), felt it was important to display the animal which was the scientific basis of the exhibition unit (EE4). The notion of displaying the specimen thus serves as an example of an exhibition strategy favoured for its traditional closeness to the scientific context. The science centre staff, on the other hand, felt that due to the beetle's small size and the lack of any inherent interactivity in a specimen display, such a display would be of relatively little interest to visitors (EE3); a point of view which is supported by research (Bitgood, Patterson, \& Benefield, 1988; Harvey, Loomis, Bell, \& Marino, 1998). Therefore, from the point of view of the science centre, the idea of exhibiting the specimen did not intersect with any visitor-related, i.e. museum-pedagogical purpose.

Dissonance in the agendas of exhibition staff is a common occurrence in exhibition engineering 
processes within the same institution (Lindauer, 2005), so it is not surprising to find such a dissonance among exhibition staff of different institutional affiliations. However, the present situation was resolved positively with the creation of the specimenbased subunit which fulfils the museums' obligation to exhibit their collections (EE4) while serving as the scientific introduction to the interactive experience (the experience-based subunit), a constellation which the science centre employs extensively (EE2). The specimen display may be seen as a component which marks an intersection between the scientific source knowledge and the exhibition's objectives, and which accordingly contributes to the integrity of the exhibition milieu of Cave Expedition.

\section{Example 2: The Creation of a Cave Beetle Habitat Analogue}

The museographic transposition of the object of knowledge the cave beetle's habitat constituted a combination of the exogenous logic of the existing reference world of the cave beetle's habitat and the endogenous logic of the museum analogue to this reference world. The creation of the cave beetle habitat analogy thus provides another example of how epistemology and museum-pedagogy may coincide, but in practice, it was not always possible for the exhibition engineers to reconcile these two logics. For example, in the first moment of transformation, the reduction of the object of knowledge the cave environment into what is basically described as a "darkened passageway" (Executive Committee, 2005b), indicates that the darkness and the enclosed space were the aspects that the exhibition engineers found to be simultaneously the most descriptive of the cave beetle's environment, the most experienceable by human visitors (EE1), and the most unproblematically realisable in terms of exhibition construction (cf. Gilbert \& Stocklmayer, 2007). However, the subsequent expansion of the cave concept in the exhibition milieu added aspects to the "darkened passageway" concept which do not reflect cave beetle habitat characteristics found in the scientific context (Figure 7). The uneven, rocklike surfaces that characterise the artificial cave arguably reflect a relatively smooth man-made passageway through rock rather than the cracks and voids that comprise the cave beetle's natural habitat, and the animal models added to the artificial cave to signify cave beetle predators seem to reflect, in scale as well as in choice of species, a human's rather than a cave beetle's experience of heterospecific animals associated with caves. Thus, the reconstitution of the cave beetle habitat in the exhibition milieu marks a departure from the endogenous logic of creating a cave beetle habitat analogue, and an implicit refocusing of the exhibit according to the exogenous logic of recreating an existing world. The world recreated is not based on the original reference world, the cave beetle's habitat, but rather on a cave environment which is recognisable as such by humans. This inference is supported by the human perspective evident in statements made by the exhibition engineers when asked to give the experiencebased subunit a one-sentence headline. The exhibition engineers described the exhibit as "a sensory tunnel" (EE1), "feel your way to the animals in the dark" (EE2), and as "the mysterious cave" (EE3). In addition, the title of the experience-based subunit, Cave Expedition, reflects a decidedly human perspective.

The integrity of the exhibition milieu is compromised by this shift of the visitor perspective. In the intersection between the scientific knowledge of the characteristics of the cave beetle's habitat and the museum-pedagogical notion of creating an analogue to that habitat, the scientific knowledge of the characteristics of the cave beetle's habitat is replaced with out-of-context ideas of what characterises a cave environment from a human perspective (Figure 7). This refocusing is perhaps not surprising, considering that in order for visitors to recognise and comprehend an immersive exhibit of a reference world recreated according to an exogenous logic, that reference world must be familiar to them (Montpetit, 1996). The inherent difficulty of creating a recognisable experience of a blind cave beetle's natural habitat for a human is perhaps best described by an expert:

[...] the cave environment is so foreign to human experience that it is often difficult to conceptualize the [environmental] parameters as they affect the inhabitants rather than from an anthropocentric point of view. (Howarth, 1983, p. 380)

The alignment of the exhibition milieu with a human perspective may consequently be an implicit attempt by the exhibition engineers to create a world which they could be certain visitors would recognise. Furthermore, a pre-existing exhibition unit titled 
Sensory Tunnel located in another part of the science centre had previously proven very popular among visitors and served as inspiration in the creation of the experience-based subunit of Cave Expedition (EE1), which may consequently have been endowed with social and psychological characteristics with proven palatability to science centre visitors (cf. Gilbert \& Stocklmayer, 2007).

\section{Example 3: The Integration of the Visitor}

The intent of the experience-based subunit of Cave Expedition is for the visitor to assume the specific role of the cave beetle by the inducement, through analogy, of a number of the cave beetle's adaptations in the visitor. Generally, an analogy describes a first subject, the target, as being equal in some sense to a second subject, the analogue (Duit, 1991). The target may be efficiently described because implicit and explicit attributes from the analogue are used to clarify the description of the target. The successful use of analogy is thus based on the existence of shared attributes between the analogue and the target (Gilbert \& Stocklmayer, 2007). In the present case, where the analogue is the human visitor's experience and the target is the cave beetle's adaptations and its resulting experience of the surroundings, the analogy depends on an overlap between the attributes of the human visitor's perceptual capacity and the beetle's adaptations. While the adaptations of the cave beetle are products of thousands or millions of years of evolution, the analogous adaptations induced in the visitor must necessarily be of a transient nature, lasting for the duration of the interaction with the exhibit. Accordingly, the substantial reduction of the object of knowledge the cave beetle's adaptations that took place in the transposition from the scientific context to the curatorial brief is a testament to both the didactic constraint of the basic biological dissimilarity between humans and cave beetles, and the museographic challenge of meaningfully and effortlessly transposing some of the more complex beetle adaptations. For example, none of the beetle's physiological adaptations were transposed to the curatorial brief or indeed the exhibition milieu. How does a cave beetle experience having reduced pigmentation and how, indeed, may that experience be meaningfully transposed to a human visitor?
Consequently, the elements of the object of knowledge the cave beetle's adaptations that were transposed to the curatorial brief were elements that were readily inducible as analogous transient behaviours or traits in the human visitor. In other words, they comprised an intersection between the scientific knowledge of the cave beetle's adaptations and the museographic objective of putting the visitor in the place of the beetle (Figure 7). Among these elements was the notion of providing the visitor with a blind person's cane as an analogue to the target: the cave beetle's elongated limbs and subsequent increased tactile range. This notion arguably would provide the visitor with the distance between the analogue and the target required in order for the analogy to work. If this ontological distance (Ogborn \& Martins, 1996) is too small, the analogy will be "too much like a close similarity and fail to excite or interest the imagination" whereas if it is larger, there is analogical work to be carried out by the visitor in terms of "probing the analogy by elaborating certain of its concrete consequences" (Ogborn \& Martins, 1996). The subsequent removal, for practical reasons, of the notion of providing the visitor with a blind person's cane in the exhibition milieu, and consequent dependence on the darkness of the artificial cave to induce an increased use of the visitor's tactile sense, accordingly marks a reduction of the ontological distance between analogue and target - a reduction which may cause the visitor to either remain ignorant of the intended analogy, or indeed to perceive their increased use of tactile sense as another component supporting the perception of the exhibit experience as that of a human, rather than a cave beetle, navigating a cave. On the other hand, the reduction of the ontological distance may also serve to remove an obstacle to visitor understanding, rendering the analogy between visitor's sense of touch and beetle's sense of touch comprehensible for the visitor.

The issue of ontological distance is relevant to several of the elements of the object of knowledge the cave beetle's adaptations that were transposed to the exhibition milieu. For example, does the inducement of temporary blindness in the visitor as an analogue to the target of the cave beetle's reduced eyes provide that analogy, or does it support the human perspective of a dark cave? The question of the appropriate ontological distance is obviously important; however, it may be more meaningfully explored in a study 
which includes visitors and their interactions and understandings of the exhibit and is thus beyond the scope of the work presented here.

\section{Example 4: Dramatisation of the Subject Matter}

The successful dramatisation of what it is like to be a cave beetle is dependent on a number of factors; some of which, as discussed in the preceding sections, support the interpretation of a cave beetle in its habitat and some of which seem to support the reconstruction of a human exploring a cave. However, only empirical studies can clarify the manner in which the dramatic conflicts in the environment are acted upon by visitors and what the visitors' resulting understanding of the plot of the drama is. Consider the spider models on the wall of the artificial cave. In order to serve the dual role of representing an aspect of the scientific knowledge (characteristics of the cave beetle's predators) and supporting the intended visitor experience (an analogy of the cave beetle's experience of a predator), the spider models should be about an order of magnitude larger than the visitor, because cave spiders may be up to an order of magnitude larger than their cave beetle prey. This notion gives rise to an interesting question about exhibition design: How would a human visitor in the dark be able to recognise a ten-metre spider model just by touching it? Instead, the use of the to-scale spider models in the artificial cave provides the visitor with instantly recognisable three-dimensional shapes which in themselves may provide dramatic conflict due to the repulsion many people have towards spiders and other "creepy-crawlies", and such a reaction could indeed be said to be a dramatic analogy of the avoidance reaction the cave beetle no doubt has to its predators.

Thus, although the model of exhibition engineering may be used to analyse the integrity of the exhibition milieu from an epistemological and museographic viewpoint, an analysis of the visitor's understanding is the logical next step towards fully evaluating the exhibition unit Cave Expedition.

\section{Museographic Transposition vs. Didactic Transposition}

A final discussion point which may serve to locate the present study within a larger context is a compa- rison between the notion of museographic transposition as developed here and the original notion of didactic transposition, i.e., the transposition that takes place in the production of the knowledge taught in a school context. The two notions have many commonalities as their common origin would suggest; however, in the following, key differences between the two will be briefly discussed.

\section{The two moments of transformation.}

Both museographic and didactic transposition take place in two moments of transformation. Didactic transposition in the school context takes place first through an external transposition regulated and rationalised by the diverse group of professionals and institutions who work with the contents of teaching at a higher level of didactic determination (e.g. ministry of education and other actors at the societal level; cf. Artigue and Winsløw, in press). The second moment of transformation is an internal didactic transposition which takes place within the educational institution -the school -and is regulated at a lower didactic level mainly by the individual teachers and their interpretation of the curriculum. The two moments of transformation in a school context may thus exist in completely separate spheres. In contrast, museographic transposition is characterised by two moments of transformation which are both regulated by roughly the same group of actors within the same institution: exhibition conceptualisers, curators, education staff, etc. The two moments of museographic transformation are accordingly regulated at much the same level of didactic determination and may therefore exert a stronger influence on each other.

However, in the present case, the immersive experience which is at the core of Cave Expedition, namely the experience of being a cave beetle, seems only distantly related to the original scientific object of knowledge and to the manner in which entomologists usually relate to that object of knowledge; to very large extent, the creation of the museographic experience was at the discretion of the exhibition engineers. Thus, in processes of museographic transposition, the semiotic transformations of the body of knowledge may play an especially important role and accordingly tend to increase the distance between the 
bodies of knowledge in the respective scientific and exhibit contexts.

Implications.

The proximity of the two moments of museographic transposition, with regard both to actors and to level of didactic determination, could have the effect of reducing the degree of dogmatisation of the scientific knowledge in the transposition process; a dogmatisation which Develay (1989) found to be characteristic of the didactic transposition of biological knowledge in a school context. Certainly, the unconstrained experiential nature of Cave Expedition in particular and perhaps immersion exhibits in general presumably allow the visitor to freely interpret their impressions and decide which are the most personally meaningful. However, Macdonald (2002) found evidence that museum visitors decoded an exhibit cluster as providing relatively dogmatic information even though the exhibit cluster was designed with no such intentions. Taken together, these findings might be cautiously extrapolated to imply that although museographic transposition provides for less dogmatised knowledge than didactic transposition in a school context, visitors may not perceive it as such.

The proximity of the two moments of museographic transposition could also have the effect of minimising the de-contextualisation and subsequent re-contextualisation of scientific knowledge which is characteristic of didactic transposition (Chevallard, 1991). In the case presented here, the biological object of knowledge was never completely separated from its context, i.e. the cave beetle and its physical habitat were present in both the contexts that preceded the exhibition milieu: the scientific knowledge and the curatorial brief. This linkage would arguably provide the exhibition engineers with background knowledge that could guide the second moment of transformation and accordingly improve the integrity of the implemented exhibit. However, the present study demonstrated the strong influence of the exhibition engineers' alternative conceptions and pedagogical considerations in the second moment of transformation; this would indicate that a stronger degree of decontextualisation and re-contextualisation takes place in museographic transposition than is the case in didactical transposition. Further studies are required to clarify the relationship between museographic transposition and didactic transposition as described by Chevallard (1991); hopefully, the present work may serve as a point of departure for such studies.

\section{Concluding Remarks}

This study offers three main contributions to the field of museum research. First, the study presents and exemplifies an analytical method applicable to the development of new exhibits as well as the post hoc analysis of existing exhibits. Taking its point of departure in the scientific body of knowledge to be transposed and mapping the changes in this body of knowledge as it is transposed to the new contexts and modalities of the curatorial brief and the exhibition milieu, the method enables the systematic tracking of the epistemological and semiotic changes in a body of knowledge in the exhibit development process. This method along with the findings it yielded here may be considered the first-order results of the present study.

The descriptive model of exhibition engineering synthesised from the analysis of museographic transposition is the second contribution of this work. The model constitutes an important step towards systematic studies of the processes and mechanics of exhibition engineering. It emphasises the dialectic relationship between scientific knowledge and museographic form and ultimately, the importance of optimising the fit between object of knowledge to-beexhibited and exhibit genre. The model constitutes what may be thought of as a second-order result of the present study.

Finally, a third-order contribution of this study to the field of museum research is the foundation that has been laid for a normative model of exhibition engineering. A study is currently under way which investigates visitor interactions with and understanding of the exhibition unit Cave Expedition on the basis of the findings presented here. This study will correlate visitor learning outcomes to the design features of the exhibit and to the considerations that drove that design, and use these correlations to expand the descriptive model of exhibition engineering into a prescriptive model for exhibition engineering. 


\section{REFERENCES}

Ansbacher, T. (1999). Experience, inquiry, and making meaning. Exhibitionist, 18(2), 22-26.

Artigue, M. and Winsløw, C. (in press). International comparative studies on mathematics education: A viewpoint from the anthropological theory of didactics. Recherches en Didactique des Mathématiques.

Belaën, F. (2003). L'analyse de l'apparition d'un nouveau genre culturel dans les musées des sciences: les expositions d'immersion. Paper presented at The International Cultural Heritage Informatics Meeting, Paris, France.

Bitgood, S. (1990). The role of simulated immersion in exhibition. (Rep. No. 90-20). Center for Social Design, Jacksonville, Alabama, USA.

Bitgood, S., Patterson, D., \& Benefield, A. (1988). Exhibit design and visitor behavior: empirical relationships. Environment and Behavior, 20(4), 474-491.

Bosch, M., \& Gascón, J. (2006). Twenty-five years of the didactic transposition. ICMI Bulletin, 58, 51-65.

Chevallard, Y. (1991). La transposition didactique: Du savoir savant au savoir enseigné. Grenoble: La Pensée Sauvage.

Clément, P. (2007). Introducing the cell concept with both animal and plant cells: A historical and didactic approach. Science \& Education, 16, 423-440.

Culver, D. C. (1982). Cave Life: Evolution and Ecology. Cambridge: Harvard University Press.

Damiano, R., Lombardo, V., \& Pizzo, A. (2005). Laying the foundations for a formal theory of drama. Lecture Notes in Artificial Intelligence, 3673, 286-289.

Davallon, J. (1999). L'exposition à l'ouvre: Stratégies de communication et médiation symbolique. Paris: L'Harmattan.

Develay, M. (1989). A propos de la transposition didactique en sciences biologiques. In G. Arsac (Ed.), La transposition didactique en mathématiques, en physique, en biologie (pp. 119-138). Lyon: IREM de Lyon and LIRDDS.

Doering, Z. D. (1999). Strangers, guests, or clients? Visitor experiences in museums. Paper presented at Managing the Arts: Performance, Financing, Service, Weimar, Germany.

Duit, R. (1991). On the role of analogies and metaphors in learning science. Science Education, 75(6), 649-672.

Executive Committee (2005a) Xtremes: final content analysis. Naturalis, KBIN, and Experimentarium.

Executive Committee (2005b) Xtremes: storyline for an exhibition about adaptations to extreme environmental conditions on Earth. Naturalis, KBIN, and Experimentarium.

Gilbert, J. K., \& Stocklmayer, S. (2007). The design of interactive exhibits to promote the making of meaning. Museum Management and Curatorship, 19(1), 41-50. 
Gouvêa de Sousa, G., Valente, M. E., Cazelli, S., Alves, F., Marandino, M., \& Falcão, D. (2002). A study of the process of museographic transposition in two exhibitions at the MAST (Museu de Astronomia e Ciências Afins). In C. Dufresne-Tassé (Ed.), Evaluation: multipurpose applied research (pp. 108-124). Québec: Éditions MultiMondes.

Harvey, M. L., Loomis, R. J., Bell, P. A., \& Marino, M. (1998). The influence of museum exhibit design on immersion and psychological flow. Environment and Behavior, 30(5), 601-627.

Hillier, B., \& Tzortzi, K. (2006). Space syntax: The language of museum space. In S. Macdonald (Ed.), A Companion to Museum Studies (pp. 282-301). Malden: Blackwell Publishing.

Howarth, F. G. (1983). Ecology of cave arthropods. Annual Review of Entomology, 28, 365-389.

Kershaw, D. R. (1988). Animal Diversity. (2nd ed.) London: Chapman \& Hall.

Lindauer, M. A. (2005). From salad bars to vivid stories: four game plans for developing 'educationally successful'exhibitions. Museum Management and Curatorship, 20(1), 41-55.

Lord, G. D. (2002). Introduction: the exhibition planning process. In B. Lord \& G. D. Lord (Eds.), The Manual of Museum Exhibitions (pp. 1-8). Walnut Creek: AltaMira Press.

Macdonald, S. (2002). Behind the scenes at the science museum. Oxford: Berg.

Miles, R. S. (1988). The design of educational exhibits. (2nd ed.) London: Routledge.

Montpetit, R. (1996). Une logique d'exposition populaire. Publics \& Musées, 9, 10-13.

Nicks, J. (2002). Curatorship in the exhibition planning process. In B. Lord \& G. D. Lord (Eds.), The Manual of Museum Exhibitions (pp. 345-371). Walnut Creek: AltaMira Press.

Novak, J. D., \& Cañas, A. J. (2008). The theory underlying concept maps and how to construct and use them. Florida Institute for Human and Machine Cognition.

Ogborn, J., \& Martins, I. (1996). Metaphorical understandings and scientific ideas. International Journal of Science Education, 18(6), 631-652.

Schauble, L., Gleason, M. E., Lehrer, R., Bartlett, K., Petrosino, A., Allen, A., ... Street, J. (2002). Supporting science learning in museums. In G. Leinhardt, K. Crowley, \& K. Knutson (Eds.), Learning Conversations in Museums (pp. 425-452). Mahwah: Lawrence Erlbaum Associates.

Simonneaux, L., \& Jacobi, D. (1997). Language constraints in producing prefiguration posters for a scientific exhibition. Public Understanding of Science, 6, 383-408. 


\section{NOTES}

1. Figure 1: The model of museographic transposition as conceptualised by Simonneaux \& Jacobi (1997), Gouvêa de Sousa et al. (2002), and in the present study.

2. Table 1: Characteristics of an immersion exhibit and their respective subcategories. The subcategories of logic of representation are mutually exclusive; the subcategories of integrating the visitor represent a range; both are from Belaën (2003). The subcategories of dramatisation of subject matter are interdependent components from Damiano et al. (2005).

3. Figure 2: Cross section of the exhibition unit Cave Expedition. The unit consisted of three text panels with the labels: (1) "Extra long legs", (2) "Cave expedition", and (3) "Check your score", as well as an artificial cave through which a passageway ran. The passageway was completely darkened and had a guide rope on the left side. On the left wall six animal models were mounted at a height of about $1 \mathrm{~m}$. The entire cave structure was about $3 \mathrm{~m}$ deep by $8 \mathrm{~m}$ long by $3 \mathrm{~m}$ high.

4. Figure 3: Illustration used in panel 1 in Cave Expedition. The illustration was accompanied by the caption: "Carabid beetles with different degrees of adaptation to their life under ground. Left: Beetles that live above ground. Right: Beetles that live under ground". ( $) 2007$ by RBINS, Experimentarium, and Naturalis. Reprinted with permission.

5. Figure 4.: Structure of the object of knowledge the adaptations of the blind cave beetle to its environment of permanently dark caves in the scientific context. The cave environment and its biotic and abiotic characteristics are shown at the top of the diagram, and the cave beetle and its morphological, physiological, and behavioural traits are shown at the bottom of the diagram. The relationships between the beetle's traits and the environmental factors are shown with connecting lines.

6. Table 2: Excerpt from the curatorial brief (Executive Committee, 2005b, p. 28) describing the scientific content and proposed exhibition unit on the blind cave beetle and its adaptations to darkness.

7. Figure 5: Structure of the object of knowledge the adaptations of the blind cave beetle to its environment of permanently dark caves in the curatorial brief. Concepts which are directly mentioned in the curatorial brief text are printed in roman, while concepts whose presence in the curatorial brief was inferred are italicised and in parentheses. Some concepts are present in both forms, e.g. elongated antennae are present both as text but also as the inferred analogy of the visitor using a blind person's cane.

8. Figure 6: Structure of the object of knowledge the adaptations of the blind cave beetle to its environment of permanently dark caves in the exhibition milieu. As in Figure 5, concepts which are explicitly present are printed in roman, while concepts which are implicitly present, such as the darkness-induced functional blindness in the visitor, are italicised and in parentheses.

9. Figure 7: Descriptive model of museographic transposition. Simultaneous processes of epistemological and museum-pedagogical development create elements of knowledge in the curatorial brief (black circles). For example, the intersection between the scientific knowledge of cave beetle adaptations such as elongated limbs and the immersion exhibit objective of integrating the visitor is exemplified by the curatorial brief notion of letting the visitor use a blind person's cane to navigate the exhibit. Elements of knowledge in the curatorial brief are then implemented by exhibition engineers to form the exhibition milieu in a process of execution. In the mentioned example, the notion of the blind person's cane as an analogy to elongated limbs is not carried through to the exhibition milieu (dotted circle). The exhibition milieu also features elements of knowledge that 
are not present in the curatorial brief, for example the animal models as cave beetle heterospecifics. Finally, some elements of knowledge in the curatorial brief are the result of museum-pedagogical but not epistemological development, for example the physical characteristics of the cave beetle's habitat (black circle with white cross). This element serves the exhibition objective of creating a cave analogy for the visitor; yet this cave analogy is not rooted in scientific knowledge about the cave beetle's habitat. 